\title{
Technical efficiency of rice production in Terai district of Nepal
}

\author{
Sanjiv Subedi ${ }^{*}$, Yuga Nath Ghimire ${ }^{1}$, Meena Kharel $^{1}$, Surya Prasad Adhikari ${ }^{1}$, \\ Jiban Shrestha ${ }^{2}$ and Bibek Kiran Sapkota ${ }^{3}$ \\ ${ }^{1}$ Nepal Agricultural Research Council, National Agricultural Policy Research Centre, \\ Khumaltar, Lalitpur, Nepal. \\ ${ }^{2}$ Nepal Agricultural Research Council, National Plant Breeding and Genetics Research Centre, \\ Khumaltar, Lalitpur, Nepal. \\ ${ }^{3}$ Himalayan College of Agricultural Sciences and Technology (HICAST), \\ Kalanki, Kathmandu, Nepal \\ *Correspondence: sanjiv.subedi@gmail.com; \\ ORCID: https://orcid.org/0000-0002-8084-008X
}

Received: June 27, 2020; Accepted: October 10, 2020; Published: October 30, 2020

(C) Copyright: Subedi et al. (2020)

(c) (1) (9)

This work is licensed under a Creative Commons Attribution-Non Commercial 4.0 International License.

\begin{abstract}
This paper aimed to estimate the technical efficiency of rice production, also identifying the factors affecting technical efficiency. Jhapa, the Terai district of Nepal, having the highest rice production in the country, was purposely selected for the study. The primary information was collected from 100 rice growing farmers, randomly selected from the sampling frame, using the pre-tested semi-structured interview schedule. Also, two Key Informant Surveys were done. Besides, the secondary information was collected by reviewing the related literatures. Descriptive statistics, stochastic frontier model with Cobb-Douglas production function, and tobit model were used for data analysis. The stochastic production frontier model revealed that with the increase in seed, chemical fertilizer, human labor, and tractor power by 1 percent, the rice yield increases by $0.25(\mathrm{P}<0.05)$, $0.15(\mathrm{P}<0.01), 0.13(\mathrm{P}<0.05)$ and $0.21(\mathrm{P}<0.01)$ percent respectively. The average technical efficiency of the rice growing farmers in the study area was estimated $92 \%$; in addition, majority of the farmers $(62 \%)$ were operating at an efficiency level of $0.91-0.95$ followed by $32 \%$ at $0.86-0.90$. The tobit regression model revealed that farming experience $(\mathrm{P}<0.01)$, membership of the organization $(\mathrm{P}<0.01)$, and major occupation being agriculture $(\mathrm{P}<0.05)$ have statistically significant and positive on technical efficiency; while, schooling years $(\mathrm{P}<0.05)$ and number of economically active family members $(\mathrm{P}<0.05)$ have statistically significant but negative effect. There is still scope to increase the rice yield through efficient use of available resources with existing technologies.
\end{abstract}

Keywords: Rice, technical efficiency, Terai, tobit regression

Correct citation: Subedi, S., Ghimire, Y.N., Kharel, M., Adhikari, S.P., Shrestha, J., \& Sapkota, B.K. (2020). Technical efficiency of rice production in terai district of Nepal. Journal of Agriculture and Natural Resources, 3(2), 32-44.

DOI: https://doi.org/10.3126/janr.v3i2.32301 
Journal of Agriculture and Natural Resources (2020) 3(2): 32-44

ISSN: 2661-6270 (Print), ISSN: 2661-6289 (Online)

DOI: https://doi.org/10.3126/janr.v3i2.32301

\section{INTRODUCTION}

Rice (Oryza sativa L.) is the member of the Poaceae family. Out of twenty three species of rice, only two species of rice have been known for their commercial value. These two species are Oryza sativa (Asian rice) and Oryza glaberrima (African rice) among which Oryza sativa is the most important commercial species of rice (CDD, 2015). Rice is the major staple food crop of Nepal. It ranks first among the cereal crops of Nepal having the highest area $(1,491,744 \mathrm{ha})$, production $(5,610,011 \mathrm{mt})$ and productivity (3.76 t/ ha) (MoALD, 2020). Moreover, Fageria (2007) reported that it is the foremost staple food for more than $50 \%$ of the world's population. There is the highest contribution of agriculture and forestry sector (28\%) to the national Gross Domestic Product (GDP) of Nepal; moreover, rice is the major agricultural crop having significant contribution to the Agriculture Gross Domestic Product (AGDP).

Rice is found to be grown in the three distinct major agro-ecological zones, which are: Terai and inner Terai (60-900 masl), Mid hills (900-1,500 masl) and Mountains/High hills (1,500 3,050 masl). Also, it has been reported that more than two third of the total rice production of Nepal is produced in the Terai. Moreover, Jhapa is the Terai district of Nepal having highest rice production in the country (MoALD, 2020). In addition, it is the first 'rice superzone' district of Nepal declared by Prime Minister Agriculture Modernization Project (PM-AMP); nearly 1000 hectares of land are required for a super zone (MoAD, 2016). The area, production and productivity of rice in Jhapa district has been reported 85,879 ha, 365,845 $\mathrm{t}$ and 4.26 t/ha respectively (MoALD, 2020).

The technical efficiency of an individual farm is defined in terms of the ratio of the observed output to the corresponding frontier output, conditional on the level of inputs used by the farm.Therefore, technical efficiency is defined as the amount by which the level of production for the farm is less than the frontier output (Kibaara, 2005). The productivity of rice could be increased through the efficient use of inputs such as: improved seed, fertilizer, human labor and farm machineries. The yield difference between improved and local varieties of rice was found to be significant at $5 \%$ level of significance in the study conducted in eastern the Terai of Nepal (Timsina et al., 2012a). Moreover, Timsina et al. (2012b) conducted a study in eastern Terai of Nepal and reported that out of 38 rice varieties released and registered for Terai and inner Terai of Nepal, about 12 varieties existed in the study area; moreover, in totality, about $67 \%$ varieties were released after $1990 \mathrm{~s}$.

It is anticipated that by the year 2025, the world's farmers should produce about $60 \%$ more rice than at present to meet the food demands of the projected world population at that time (Fageria, 2007). Lots of attempts and new ideas are emerging to increase the productivity of rice (Uprety, 2006). Improving the technical efficiency might be the appropriate means to increase the yield. Due to inadequate knowledge on optimum use of resources, most of the farmers are using the inputs in an unscientific manner which has resulted to low yield and efficiency. Ahmad et al. (2006) reported that in general, the agricultural input resources are being inefficiently utilized, especially in the under-developed countries. Also, it has been reported that improved efficiency results to increased output and yield without additional inputs and production technologies (Bravo-Uretra and Pinheiro 1997). 
The farmers could produce maximum output from the given level of input resources, if their farming practice is technically efficient (Chiona, 2011). It is therefore appropriate option for developing countries like Nepal, to increase the yield of major staple food crop- rice, by improving the technical efficiency through efficient use of available resources. Bajracharya et al. (2017) conducted a study on technical efficiency of certified maize seed in Palpa district of Nepal. Moreover, Adhikari et al. (2018) also conducted a research to estimate the technical efficiency of hybrid maize production in eastern Terai of Nepal. However, an assessment on technical efficiency of rice production is lacking. This paper aims to estimate the technical efficiency of rice growing farmers and identify the factors affecting it. This shows the way to increase the yield by possible improvement in efficiency without increasing the resource. Moreover, this study also explores the areas where the major interventions are needed to be done to improve the efficiency and increase the yield.

\section{METHODOLOGY}

\section{Study area}

Jhapa district was purposely selected for this study. Jhapa is the Terai district of Nepal having the highest rice production in the country. Moreover, it is the first rice super zone district declared by PM-AMP, MoALD. The study sites selected for the study purpose in Jhapa were: Gauradaha municipality, Gaurigunj rural municipality, Birtamod municipality, Arjundhara municipality and Kanchankawal rural municipality. These sites were selected on the basis of consultation with the agricultural officials of rice super zone, Agriculture Knowledge Centre and the local government.

\section{Sampling procedure and data collection}

The sampling frame of the rice growing farmers in the study area was obtained in coordination with rice super zone office, Jhapa. Then, the simple random method of sampling was applied to select the sample from the sampling frame. The primary information was collected using the pre-tested interview schedule; also, two Key Informant Surveys were done. Moreover, related literatures were reviewed to collect the secondary information. All total, 100 samples were taken from the study sites for the purpose of the study.

\section{Methods and techniques of data analysis}

The collected data were coded and entered into the computer for further analysis. Data entry was done in MS-Excel and analysis was done using the packages, STATA and Statistical Package for Social Science (SPSS). The following analyses were done.

\section{Statistical description of the socio-economic and demographic characteristics}

The statistical description of the continuous variables used in the tobit model was done by estimating the mean and standard deviation while for dummy variables; the frequency and percentage were calculated.

\section{Econometric model}

The estimation of technical efficiency was done using the econometric modeling according to the stochastic frontier methodology of Aigner et al. (1977). The stochastic frontier method is a parametric approach that estimates technical efficiency within a stochastic production 
function model (Chakraborty et al. 2002; Coelli et al. 2005). The technical efficiency was predicted by using the stochastic frontier model with Cobb-Douglas production function.

\section{Cobb-Douglas frontier production function model}

The Cobb-Douglas production function has been widely used in many empirical studies, particularly in developing countries for the analysis of farm efficiency (Bravo-Ureta and Pinheiro 1997; Bajracharya, 2017; Adhikari, 2018). In this study, we used the Cobb-Douglas frontier production function model described below.

$\ln Y=\ln a+b_{1} \ln X_{1}+b_{2} \ln X_{2}+b_{3} \ln X_{3}+b_{4} \ln X_{4}+u$

Where,

$\mathrm{Y}=$ Yield $(\mathrm{Kg} / \mathrm{ha})$

$\mathrm{X}_{1}=$ Quantity of seed used $(\mathrm{Kg} / \mathrm{ha})$

$\mathrm{X}_{2}=$ Quantity of chemical fertilizers used $(\mathrm{Kg} / \mathrm{ha})$

$\mathrm{X}_{3}=$ Human labor used (man-days/ ha)

$\mathrm{X}_{4}=$ Tractor power used (hours/ ha)

$\mathrm{u}=$ Random disturbance term or error term

$\mathrm{a}=$ Intercept or constant term

$\mathrm{e}=$ Base of natural logarithm

ln = Natural logarithm

$b_{1}, b_{2}, b_{3}$ and $b_{4}=$ Coefficients of respective variables.

\section{Estimation of technical efficiency (TE)}

The methodology for assessment of technical efficiency was used taking the reference of book by Coelli et al. (2005). Moreover, Aigner and Chu (1968) used the Cobb-Douglas production frontier to estimate the stochastic production frontier of the form:

Ln $\mathrm{q}_{\mathrm{i}}=\mathrm{x}_{\mathrm{i}} \mathrm{b}-\mathrm{u}_{\mathrm{i}} \ldots \ldots . .(1)$

Where,

$q_{i}$ represents the output; $x_{i}$ is $K^{*} 1$ vector which contains logarithms of inputs; $b$ is a vector of unknown parameters and $\mathrm{u}_{\mathrm{i}}$ is non-negative random variable which is associated with technical inefficiency. Also, Aigner et al. (1977) proposed the stochastic frontier production function model independently, which was,

$\operatorname{Ln} \mathrm{q}_{\mathrm{i}}=\mathrm{x}_{\mathrm{i}} \mathrm{b}+\mathrm{v}_{\mathrm{i}}-\mathrm{u}_{\mathrm{i}}$

This equation 2 is identical to the equation 1 except $v_{i}$. Here $v_{i}$ (symmetric random error) was added to account for statistical noise. The model defined in equation 2 is called as a stochastic frontier production method. In addition, Battese (1992) and Rahman (2003) applied the stochastic production frontier method to estimate the technical efficiency. The half-normal distribution is assumed for the asymmetric technical inefficiency parameter in this study. The farm specific technical efficiency $\left(\mathrm{TE}_{\mathrm{i}}\right)$ of the $\mathrm{i}^{\text {th }}$ sample farmer was estimated by using the formula;

$\mathrm{TE}_{\mathrm{i}}=\frac{\mathrm{q}_{\mathrm{i}}}{\exp \left(\mathrm{x}_{\mathrm{i}}^{s} \beta+\mathrm{v}_{\mathrm{i}}\right)}=\frac{\exp \left(\mathrm{x}_{\mathrm{i}}^{\circ} \beta+\mathrm{v}_{\mathrm{i}}-\mathrm{u}_{\mathrm{i}}\right)}{\exp \left(\mathrm{x}_{\mathrm{i}}^{\circ} \beta+\mathrm{v}_{\mathrm{i}}\right)}=\exp \left(-\mathrm{u}_{\mathrm{i}}\right)$

The ratio of observed output to the corresponding stochastic frontier output. The measure of technical efficiency takes a value between zero and one. It measures the output of the firm relative to output that could be produced by a fully efficient firm using the same input vector. $\mathrm{Y}=\mathrm{f}\left(\mathrm{X}_{\mathrm{i}} ; \mathrm{b}_{\mathrm{i}}\right)+1$

The error term is composite (Chavas et al., 2005; Rahman, 2003; Sharma \& Leung, 2000; Bravo-Ureta \& Pinheiro 1993; Ali \& Flinn, 1989). 
Thus,

$\mathrm{L}=\mathrm{v}-\mathrm{u}$

Where $\mathrm{v}$ is a two-sided $(-\infty<v<\infty)$ normally distributed random error $\left[\mathrm{V} \approx \mathrm{N}\left(0, \mathrm{sd}^{2}{ }_{\mathrm{v}}\right]\right.$ that captures the stochastic effects outside the farmer's control (e.g., weather, natural disasters and luck), measurement errors, and other statistical noise. The term $u$ is a one-sided $(u \geq 0)$ efficiency component that captures the technical inefficiency of the farmer. It measures the shortfall in output from its maximum value given by the stochastic frontier. The study assumed $u$ has an exponential distribution $\left[\mathrm{U} \approx \mathrm{N}\left(0, \mathrm{sd}^{2} \mathrm{u}\right)\right]$. The two components $v$ and $u$ are also assumed to be independent of each other. Technical efficiency levels were predicted from the stochastic frontier production function estimation. The technical efficiency score was obtained and categorized in an interval of 5.

\section{Tobit regression model}

The tobit regression was used to determine the socio-economic and demographic characteristic factors affecting the technical efficiency. The technical efficiency was a continuous variable which value could range from 0 to 1 . The past researches showed that the tobit model has been widely used to determine the factor affecting technical efficiency (Nyagaka, Obare \& Nguyo, 2010). The equation of the tobit regression model used is described below;

$\mathrm{Y}_{\mathrm{i}}^{*}=\mathrm{X}_{\mathrm{i}} \mathrm{b}_{\mathrm{i}}+\mathrm{e}_{\mathrm{i}}$

Where, $\mathrm{Y}_{\mathrm{i}}{ }^{*}$ is latent variable for the $\mathrm{i}^{\text {th }}$ rice growing farmers and the values was censored at 0 and $100 . X_{i}$ were the explanatory variables used in models, $b_{i}$ were the estimated coefficient and $e_{i}$ was the distributed error term which was assumed to be normally distributed at zero mean and constant variance.

The Tobit model used in this study was;

$\mathrm{Y}=\mathrm{b}_{0}+\sum_{\mathrm{n}=1}^{9} \mathrm{~b}_{\mathrm{n}} \mathrm{X}_{\mathrm{n}}+\mathrm{e}_{\mathrm{i}}$

Where,

$\mathrm{X}_{1}=$ Age (Age of the household head; in years)

$\mathrm{X}_{2}=$ Schooling_yrs (Schooling of the household head; in years)

$\mathrm{X}_{3}=$ Membership (Membership of any organization; Yes=1, otherwise 0)

$\mathrm{X}_{4}=$ Farm_exp (Experience on rice production; in years)

$\mathrm{X}_{5}=$ Seed source (Seed source if cooperatives/government farms $=1$, otherwise 0 )

$\mathrm{X}_{6}=$ Fm_15_59 (Economically active family members; in number)

$\mathrm{X}_{7}=$ Subsidy (Subsidy in rice farming; Yes=1, otherwise 0)

$\mathrm{X}_{8}=$ Maj_occup (Major occupation of the farm household; Agriculture $=1$ otherwise 0 )

$\mathrm{X}_{9}=\mathrm{Ln} \_$rice_land (Area of rice cultivated land in hectare; in natural $\log$ )

$\mathrm{b}_{0}=$ Constant

$\mathrm{e}_{\mathrm{i}}=$ Error term

$\mathrm{Y}=$ Technical efficiency scores (in \%)

The maximum likelihood estimation was used for tobit regression analysis.

\section{RESULTS}

\section{Description of the socio-economic and demographic variables}

The statistical analysis of the socio-economic and demographic variables was done by using descriptive statistics; measures of central tendency such as mean and standard deviation was used for continuous variables while measures of dispersion such as percentage, frequency 
was used for the categorical variables. The average age, schooling and farming experience of the respondent were found to be $48.7,8.5$ and 13.2 years respectively; the family size and number of economically active family members were estimated 5 and 3 respectively. Moreover, average rice cultivated area and rice productivity of the respondents in the study area were calculated 1.6 ha and $4500 \mathrm{~kg} / \mathrm{ha}$ respectively (Table 1).

Table 1. Scio-economic and demographic characteristics of the respondents $(N=100)$

\begin{tabular}{lcc}
\hline Continuous variables & Mean & Standard deviation \\
\hline Age of the household head (in years) & 48.7 & 11.02 \\
Schooling years of the household head (in years) & 8.5 & 4.01 \\
Family size (in number) & 5.1 & 1.80 \\
Economically active family members (in number) & 3.3 & 1.55 \\
Farming experience (in years) & 13.2 & 8.03 \\
Area of rice cultivated land (in ha) & 1.6 & 2.62 \\
Rice productivity (kg/ha) & 4500 & 1192.84 \\
\hline Dummy variables & Frequency & Percentage \\
\hline Membership of any organization (Yes=1) & 71 & 71 \\
Seed source if cooperatives/government farms (Yes=1) & 47 & 47 \\
Subsidy in rice farming (Yes=1) & 39 & 39 \\
Major occupation of the farm household, if agriculture (Yes=1) & 68 & 68 \\
\hline
\end{tabular}

Source: Field survey, 2020

\section{Stochastic production frontier model}

The wald chi-square value was found to be highly significant which indicated that the model has good explanatory power at the $1 \%$ level. This means that the explanatory variables included in the model were enough to describe the variation in the dependent variable. Moreover, the model revealed that with the increase in seed, chemical fertilizer, human labor and tractor power by 1 percent, the rice yield increases by $0.25(\mathrm{P}<0.05), 0.15(\mathrm{P}<0.01), 0.13$ $(\mathrm{P}<0.05)$ and $0.21(\mathrm{P}<0.01)$ percent respectively. Also, the sum of the estimated coefficients of all the inputs of rice production was calculated 0.74 which indicated that the production function exhibited a decreasing return to scale; implies that if all the inputs specified in the function are increased by $1 \%$, the output from rice production will increase by $0.74 \%$ (Table 2).

Table 2. Stochastic production frontier of rice production

\begin{tabular}{|c|c|c|c|c|}
\hline Variables & Coefficients & Standard error & $\mathbf{z}$ & $\mathbf{P}>\mathbf{z}$ \\
\hline Log seed (kg/ha) & $.2549 * *$ & .1011 & 2.52 & 0.012 \\
\hline Log chemical fertilizer (kg/ha) & $.1541 * * *$ & .0405 & 3.80 & 0.000 \\
\hline Log human labor (man-days/ha) & $.1342 * *$ & 0558 & 2.40 & 0.016 \\
\hline Log tractor power (hours/ha) & $.2055 * * *$ & 0729 & 2.82 & 0.005 \\
\hline Constant & $5.8091 * * *$ & 4041 & 14.38 & 0.000 \\
\hline sigma_v & 1915 & 0135 & & \\
\hline sigma_u & .0020 & 2124 & & \\
\hline sigma2 & 0367 & .0052 & & \\
\hline Lambda & 0106 & 2136 & & \\
\hline \multicolumn{5}{|l|}{ Summary statistics } \\
\hline Number of observations & 100 & & & \\
\hline Wald $\operatorname{chi}^{2}(4)$ & 75.68 & & & \\
\hline Prob $>$ chi $^{2}$ & 0.0000 & & & \\
\hline Log likelihood & 23.3474 & & & \\
\hline
\end{tabular}


Journal of Agriculture and Natural Resources (2020) 3(2): 32-44

ISSN: 2661-6270 (Print), ISSN: 2661-6289 (Online)

DOI: https://doi.org/10.3126/janr.v3i2.32301

\section{Estimation of technical efficiency}

The prediction of the technical efficiency of rice production revealed that majority of the farmers (62\%) were operating at efficiency level of $0.91-0.95$ followed by $32 \%$ at $0.86-0.90$ (Table 3). The average technical efficiency of rice production was estimated 0.92 (92\%); the minimum and maximum values were 0.86 and 0.95 respectively (Table 4 ). The average value of technical efficiency (92\%) indicated that technically, the rice production in the study area is highly efficient; however, there is still scope to increase it by nearly $8 \%$ through proper allocation of available resources and technology.

Table 3. Overall technical efficiency of rice production

\begin{tabular}{llllll}
\hline Variables & Observations & Mean & Standard deviation & Minimum & Maximum \\
\hline Technical efficiency & 100 & 0.917 & 0.027 & 0.863 & 0.954 \\
\hline Source: Field survey, 2020 & & & &
\end{tabular}

Table 4. Percentage of farmers operating at different technical efficiency level

\begin{tabular}{ll}
\hline Technical efficiency level & Percentage of farmers \\
\hline $0.86-0.90$ & 38 \\
$0.91-0.95$ & 62 \\
\hline
\end{tabular}

Source: Field survey, 2020

\section{Factors affecting the technical efficiency}

The tobit model was used to identify the determinant factors affecting the technical efficiency. For this, the predicted technical efficiency score (in percent) of the rice growing farmers was used as dependent variable and their major socio-economic and farm characteristics were used as the explanatory variables. The value of likelihood ratio (81.91) was statistically significant at $1 \%$ level which indicated that the model has good explanatory power. The value of pseudo $\mathrm{R}^{2}$ was estimated 0.17 , which showed that the $17 \%$ of the variation in technical efficiency is explained by the explanatory variables included in the model. The interpretation is shown in table 5.

Table 5. Factors affecting the technical efficiency of rice production

\begin{tabular}{|c|c|c|c|c|}
\hline Variables & Coefficients & Standard error & t-value & p-value \\
\hline Age & -.0096 & .0204 & -0.47 & 0.638 \\
\hline Schooling_yrs & $-.1510 * *$ & .0605 & -2.49 & 0.014 \\
\hline Membership & $2.0272 * * *$ & .4154 & 4.88 & 0.000 \\
\hline Farrming_exp & $.1946 * * *$ & .0323 & 6.02 & 0.000 \\
\hline Seed source & .0056 & .4676 & 0.01 & 0.990 \\
\hline Fm_15_59 & $-.2743 * *$ & .1059 & -2.59 & 0.011 \\
\hline Subsidy & .1400 & .4275 & 0.33 & 0.744 \\
\hline Major_occup & $1.4002 * *$ & .4274 & 3.28 & 0.001 \\
\hline Ln_rice_land & -.2916 & .2406 & -1.21 & 0.229 \\
\hline Constant & $90.8769 * * *$ & 1.4837 & 61.25 & 0.000 \\
\hline \multicolumn{5}{|l|}{ Summary statistics } \\
\hline Number of observations & 100 & & & \\
\hline $\operatorname{LR} \operatorname{chi}^{2}(9)$ & 81.91 & & & \\
\hline Prob $>\mathrm{chi}^{2}$ & 0.0000 & & & \\
\hline Pseudo $\mathrm{R}^{2}$ & 0.1704 & & & \\
\hline Log likelihood & -199.4499 & & & \\
\hline
\end{tabular}


The model revealed that with the one year increase in schooling years, the technical efficiency decreases by $0.15 \%(\mathrm{P}<0.05)$; while with the unit year increase in farming experience, the technical efficiency increases by $0.19 \%(\mathrm{P}<0.01)$. Moreover, the technical efficiency of the farmers having membership of the organization was found to be $2 \%$ more $(\mathrm{P}<0.01)$ than that of those who don't have. In addition, with the unit increase in number of economically active family members in the family, the technical efficiency decreases by $0.27 \%(\mathrm{P}<0.05)$. Furthermore, the technical efficiency was found to be $1.4 \%$ more $(\mathrm{P}<0.05)$ for the farmers whose major occupation is agriculture, as compared to those whose major occupation is otherwise (Table 5).

\section{DISCUSSION}

\section{Stochastic frontier model}

The stochastic frontier model has revealed positive and statistically significant relationship between the inputs (seed, chemical fertilizer, human labor and tractor power) used in rice production and the yield. Bajracharya and Sapkota (2017) also reported significantly positive influence of seed, labor and tractor power on yield of maize. In addition, Lamichhane et al. (2019) also reported positive and significant relationship between quantity of seed, fertilizer, and labor use and the yield. Moreover, Dube et al. (2018) reported that quantity of seed and labor were found to have positive and significant effect on yield. Also, Dessale (2019) reported that the maximum likelihood parameter estimates showed that wheat output was positively and significantly influenced by fertilizer and labor.

\section{Technical efficiency of rice production}

The average technical efficiency of the farmers in the study area was estimated $92 \%$; in addition, majority of the farmers (62\%) were operating at efficiency level of 0.91- 0.95 which showed that the resources are allocated efficiently in rice production. As Jhapa is the rice super zone district and the highest rice producing district of Nepal (MOAD, 2020), the higher technical efficiency of the majority farmers revealed from this study is not surprising. Also, in overall, there is still scope to increase $8 \%$ efficiency with the rationale allocation of available resources; the adjustment in resource use should be made taking account of the estimated coefficients of the inputs revealed from the Cobb-Douglas frontier production function. In a synonymous manner, Wabomba (2015) also found that more than one third $(40.5 \%)$ of the farmers had technical efficiency measure of $90 \%$ and above in soyabean production in Kenya. Moreover, it has been reported that the estimated mean technical efficiency of the farmers in wheat production in Ethopia was about 82\% (Dessale, 2019). In contrary to this, Oluwatayo, Sekumade and Adesoji (2008) reported the average technical efficiency of maize farmers to be $68 \%$ in rural Nigeria. Also, the average technical efficiency of maize and beans in Nicaragua was found $69.8 \%$ and $74.2 \%$ respectively estimated by using the translog stochastic frontier model (Abdulai and Eberlin, 2001).

\section{Factors affecting the technical efficiency}

The tobit regression model revealed that schooling years and number of economically active family members have negative and significant effect on technical efficiency; while, farming experience, membership of the organization and major occupation being agriculture have positive and significant effect. 
With the higher level of formal education, the household head might be engaged in service and other educational activities due to which he/she would have neglected or given less time to the agricultural production. Also, might have got less time to consult with the agricultural technician regarding adoption of improved varieties and technologies which ultimately results low yield. Subedi et al. (2017) reported that the probability of adoption of improved varieties by the farmer increases with the increased consultation with the agricultural technician. Also, the negative influence of formal education towards adopting genetically modified crops has been reported (Uematsu and Mishra, 2010). The findings of this study are in contrary to the findings of Assadullah and Rahman (2009) and Ajewole and Folayan (2008).

The population belonging to the age group 15-59 years is considered as the economically active population by the Government of Nepal (CBS, 2012). It has been revealed that the negative relationship exists between the technical efficiency and number of economically active population. Subedi et al. (2020) also reported the negative relationship between number of economically active population and the total quantity of wheat produced. This might be due to the reason that the members of this age group might have been engaged either in service, business or employed elsewhere other than agricultural production.

Moreover, it has been revealed that the farming experience has positive relation with technical efficiency. With the increased farming experience, farmers acquire knowledge and skills necessary for choosing appropriate new farm technologies and have idea on efficient use of resources. The finding was in line with the findings of Olarinde (2011) and Gul et al. (2009); however, contrary to the findings of Ajewole and Folayan (2008).

Also, the membership of organization was found to have positive and significant effect to technical efficiency. Being the member of the organization such as cooperatives, farmers' group, farmers got opportunity to interact with each other in different meetings and trainings and learn about the improved agricultural technologies. This motivates them towards adoption of such technologies which ultimately contributes to higher yield and make them technically efficient.

In line of this, Uaiene et al. (2009) reported that the individual decisions are affected by social network effects, and that in the context of agricultural Innovations, farmers interact, share and learn from each other. Also, Subedi et al. (2019) had also reported that the farmers who have membership of any organization had 15\% more probability for adoption of improved varieties as compared to those who haven't.

Furthermore, it has been revealed from this study that the farm households having agriculture as their major occupation have higher technical efficiency as compared to the counterparts. The investment of time, money and effort in rice production will be with great care if the major occupation is agriculture; also, the farmer will be more responsive towards adoption of improved agricultural technologies. Ultimately, this results to increased yield and high technical efficiency.

Subedi and Dhakal (2015) also reported that the probability of adoption of improved agricultural technologies is significantly more for the farm households whose major occupation is agriculture as compared to those whose major occupation is otherwise. Also, Mottaleb (2018) reported that the farm households having agriculture as their major 
occupation are dependent on agriculture for their livelihoods, thus are more eager to adopt improved agricultural technologies agricultural machinery than others.

\section{CONCLUSION}

The average technical efficiency of rice production predicted from stochastic frontier model was more than ninety percent; majority of the rice growing farmers were operating at this efficiency level. This showed the efficient allocation of input resources in rice production in the study area; however, there is still scope to improve the technical efficiency. Moreover, the study revealed that the technical efficiency could be improved by improving the knowledge and skills of the farmers through informal education such as trainings and seminars rather than formal; motivating the farmers of economically active age group is the most. Also, the farmers should be encouraged to be the member of agricultural organization such as cooperatives, farmers' group; membership of experienced farmers in such organization will have positive multiplier effect to technical efficiency. The government should encourage the farm households to adopt agriculture as their major occupation through different supportive policies of grants, subsidies and technical assistance. In the developing countries like Nepal, the efficient allocation of input resources and wise use of existing technologies could increase the yield to certain level, eventhough new technologies are not introduced.

\section{Acknowledgements}

The authors would like to thank Nepal Agriculture Research Council (NARC) for providing the fund to accomplish this study. They would like to express their gratitude to their colleagues and heartiest thanks owed to the respondents of the study area for giving the valuable information.

\section{Author's Contribution}

S. Subedi designed the research plan. S.Subedi, M. Kharel and S.P. Adhikari collected the data; B.K. Sapkota designed a data entry template in MS excel and entered the data. S. Subedi analyzed the data and prepared the manuscript. Y.N Ghimire and Jiban Shrestha provided comments and feedback to finalize this manuscript. Final form of manuscript was approved by all authors.

\section{Conflict of Interest}

The authors declare that there is no conflict of interest with present publication.

\section{REFERENCES}

Abdulai, A., \& Eberlin, R. (2001). Technical efficiency during economic reform in Nicaragua:Evidence from farm household survey data. Economic systems, 25(2), 113125.

Adhikari, S.P., Timsina, K.P., Brown P.R., \& Lamichhane, J.(2018). Technical efficiency of hybrid maize production in eastern terai of Nepal: A stochastic frontier approach. Journal of Agriculture and Natural Resources, 1(1), 189-196

Ahmad, B., \& Abedullah, B.K. (2006). Technical efficiency and its determinants in potato production, evidence from Punjab, Pakistan. Lahore J Econ, 11(2),1-22 
Aigner, D. J., \& Chu, S. F. (1968). On estimating the industry production function. The American Economic Review, 58(4), 826-839.

Aigner, D. J., Lovell, C. A. K., \& Schmidt, P. (1977). Formulation and estimation of stochastic frontier production function models. Journal of Econometrics, 6(1), 21-37.

Ajewole, O.C. \& Folayan, J. A. (2008). Stochastic frontier analysis of technical efficiency in dry season leaf vegetable production among smallholders in Ekiti State, Nigeria. Agricultural Journal, 3(4), 252-257.

Ali, M., \& Flinn, J. C. (1989). Profit efficiency among Basmati rice producers in Pakistan Punjab. American Journal of Agricultural Economics, 71(2), 303-310.

Asadullah, M. \& Rahman, S. (2009). Farm productivity and efficiency in rural Bangladesh: The role of education revisited. Applied Economics, 41(1),17-33.

Bajracharya, M., \& Sapkota, M. (2017). Technical efficiency of certified maize seed in Palpa district, Nepal: A stochastic frontier production approach. Journal of Maize Research and Development, 3(1), 45-52. DOI: http://dx.doi.org/10.3126/jmrd.v3i1.18920.

Battese, G. E. (1992). Frontier production functions and technical efficiency: a survey of empirical applications in agricultural economics. Agricultural economics, 7(3), 185208.

Bravo-Ureta, B.E., \& Pinheiro, A.E. (1997). Technical, economic and allocative efficiency in peasant farming: evidence from the Dominican Republic Dev Econ,34, pp.48-67

Bravo-Ureta, B. E., \& Pinheiro, A. E. (1993). Efficiency analysis of developing country agriculture:A review of the frontier function literature. Agriculture and resource economics review, 22(1),88-101.

CDD.(2015). Rice Varietal Mapping in Nepal: Implication for Development and adoption. Hariharbhawan, Kathmandu: : Ministry of Agricultural Development.

Chakraborty, C., Mishra, S.K., \& Johnson, P.N.(2002). Cotton farmer's technical efficiency: Stochastic and non stochastic production function approaches. Agricultural and Resource Economics Review , 31, 211-220

Chavas, J. P., Petrie, R. \& Roth, M. (2005). Farm household production efficiency: Evidence from the Gambia. American Journal of Agricultural Economics, 87(1), 160-179.

Chiona, S. (2011). Technical and Allocative Efficiency of Smallholder Maize Farmers in Zambia (A master thesis ).University of Zambia, Lusaka.

Coelli, T.J., Rao, D.S.P., O'Donnell, C.J., \& Battese, G.E. (2005). An introduction to efficiency and productivity analysis:Springer Science \& Business Media.

Dessale, M. (2019). Analysis of technical efficiency of small holder wheat-growing farmers of Jamma district, Ethiopia. Agriculture and Food Security, 8(1), 4-8. https://doi.org/10.1186/s40066-018-0250-9

Dube, A.K., Ozkan, B., Ayele, A., Idahe, D., \& Aliye, A. (2018). Technical efficiency and profitability of potato production by smallholder farmers: The case of Dinsho District, Bale Zone of Ethiopia. Journal of Development and Agricultural Economics, 10(7), 225-235.

Fageria, N. (2007). Yield physiology of rice. Journal of Plant Nutrition, 30, 843-879.

Gul, M., Koc, B., Dagistan, E., Akpinar, M. G., \& Parlakay, O. (2009). Determination of technical efficiency in cotton growing farms in Turkey: A case study of Cukurova region. African journal of Agricultural research, 4(10), 944-949.

Kibaara, B.W. (2005). Technical efficiency in Kenyan's maize production: An application of the stochastic frontier approach(Unpublished MSc thesis). Department of Agricultural and Resource Economics, Colorado State University. 
Lamichhane, J., Acharya, B., \& Sharma, T.(2019). Technical efficiency of potato production in mid western terai region of Nepal. Journal of Agriculture and Natural Resources, 2(1), 244-251. DOI: https://doi.org/10.3126/janr.v2i1.26082

MOAD.(2016). Prime Minister Agriculture Modernization Project (PMAMP) Final Cabinet Document. Ministry of Agricultural Development, Government of Nepal, Singhadarbar, Kathmandu, Nepal.

MoALD.(2020).Statistical Information on Nepalese Agriculture 2018/2019.Agri Statistics Section, Monitoring, Evaluation and Statistics Division. Singha Durbar, Kathmandu, Nepal: Ministry of Agricultural Development.

Mottaleb, K.A. (2018). Perception and adoption of a new agricultural technology: Evidence from a developing country. Elsevier: Technology in Society, 55, 126-135.

Nyagaka, D. O., Obare, G. A., Omiti, J. M., \& Nguyo, W. (2010). Technical efficiency in resource use: Evidence from smallholder Irish potato farmers in Nyandarua North District, Kenya. African Journal of Agricultural Research, 5(11), 1179-1186.

Olarinde, L. O. (2011). Analysis of technical efficiency differentials among maize farmers in Nigeria. The African Economic Research Consortium. Ladoke Akintola University of Technology, Nigeria. ISBN: 978-9966-023-04-9

Oluwatayo, I.B., Sekumade, A.B., \& Adesoji, S. A. (2008). Resource use efficiency of maize farmers in rural Nigeria: Evidence from Ekiti State. World Journal of Agricultural Sciences, 4(1), 91-99.

Rahman, S. (2003). Profit efficiency among Bangladeshi rice farmers. Contributed paper for the 25th conference of the International Association of Agricultural Economists, Durban, South Africa, August, 2003.

Sharma, K.R. \& Leung, P.S. (2000). Technical efficiency of carp production in India: a stochastic frontier production function analysis. Aquaculture Research, 31, 937-947.

Subedi, S. \& Dhakal, D. (2015). Economics of poultry manure as an alternative to chemical fertilizer for agricultural production in Nepal. Journal of Institute of Agriculture and Animal Sciences, 33,259-268.

Subedi, S., Ghimire, Y.N., \& Devkota, D. (2017). Socio-economic assessment on maize production and adoption of open pollinated improved varieties in Dang, Nepal. Journal of Maize Research and Development, 3 (1), 17- 27. DOI: http://dx.doi.org/10.3126/jmrd. v3i1.18916.

Subedi, S., Ghimire, Y. N., Devkota, D., Kharel, M., Gautam, S., Sharma, B., \& Sapkota, B. K. (2020). Socio-economics of wheat production in Kailali and Sunsari districts of Nepal. Journal of Agriculture and Natural Resources, 3(1), 29-37. DOI: https://doi.org /10.3126/ janr. v3i1.27003

Subedi, S., Ghimire, Y.N., Adhikari, S.P., Devkota, D., Shrestha, J., Poudel, H.K. \& Sapkota, B.K. (2019). Adoption of certain improved varieties of wheat (Triticum aestivum L.) in seven different provinces of Nepal. Archives of Agriculture and Environmental Science, 4(4), 404-409, https://dx.doi.org/10.26832/ 24566632.2019.040406

Timsina, K.P., Bista, H.B., Gauchan, D., Sapkota, B., Ghimire, Y.N., Shrestha K.P., \& Shrestha, B. (2012a). Adoption Analysis of Rice Varieties in Terai of Nepal. In the proceeding of 10th National Outreach Research Workshop held at Regional Agricultural Research Station, Lumle, from 27-28 February, 2012. Nepal Agricultural Research Council (NARC) \& Outreach Research Division (ORD), Khumaltar, Nepal, 295-301 Pp 
Journal of Agriculture and Natural Resources (2020) 3(2): 32-44

ISSN: 2661-6270 (Print), ISSN: 2661-6289 (Online)

DOI: https://doi.org/10.3126/janr.v3i2.32301

Timsina, K.P., Shrestha, K.P., \& Pandey, S. (2012b). Factors affecting adoption of new modern varieties of Rice in eastern Terai of Nepal. In the proceeding of 4th Society of Agricultural Scientist-Nepal (SAS-N) conference held at Lalitpur from 4-6 April, 2012. Nepal Agricultural Research Council (NARC) and Society of Agricultural Scientists (SAS-N), Nepal, 48-54 Pp.

Uaiene, R., Arndt, C., \& Masters, W. (2009). Determinants of Agricultural Technology Adoption in Mozambique. Discussion papers No. 67E.

Uematsu, H., \& Mishra, A. (2010). Can Education Be a Barrier to Technology Adoption?.Selected Paper prepared for presentation at the Agricultural \& Applied Economics Association 2010 AAEA,CAES, \& WAEA Joint Annual Meeting, Denver, Colorado, 25-27.

Uprety, R. ( 2006). SRI takes root in Nepal. Low External Input Sustainable Agriculture,22 (4), 26-27.

Wabomba, O. W. (2015). Determinants of technical efficiency of soybean production among farmers in Bungoma County, Kenya (M. Sc. Thesis). Department of agricultural economics and resource management, school of business and economics, MOI University. 